\title{
Analysis on the Construction of Comprehensive Grain Logistics Park in LY City of Hunan Province
}

\author{
Shijun Yuan \\ Hunan Modern Logistics College \\ Changsha, China 410131
}

\author{
Xiangyang Liao \\ Hunan Modern Logistics College \\ Changsha, China 410131
}

\author{
Jianhua Chen* \\ Hunan Modern Logistics College \\ Changsha, China 410131 \\ *Corresponding Author
}

\begin{abstract}
In order to promote the development of local grain industry, LY City, Hunan Province, plans to build a comprehensive grain logistics park. This paper analyzes the total logistics market and its development space, demand environment of logistics market, and need of logistics service modes, to provide reference suggestions for project construction.
\end{abstract}

\section{Keywords—logistics park; construction; market analysis}

\section{INTRODUCTION}

Grain logistics connects with production and consumption, which is conducive to maintaining the basic balance of grain market. However, in general, Chinese grain logistics still stays at the traditional level. The lagging construction of Chinese grain logistics system has become a major obstacle to restrict grain circulation. The contradiction between the objective requirement and the actual situation of grain logistics development has become the main one in the development of grain circulation in China. To promote the development of the local grain logistics industry, LY City, Hunan Province, plans to build a comprehensive grain logistics park in LY City.

\section{ANALYSIS OF TOTAL LOGISTICS MARKET AND ITS DEVELOPMENT SPACE IN LY CITY}

\section{A. Estimation of Total Logistics Market in LY City}

LY City achieved a total output value of RMB 17.6 billion, an increase of $14.8 \%$, calculated at comparable prices, over the previous year. The added value of primary industry, secondary industry and tertiary industry was respectively RMB 2.805 billion, 9.888 billion and 4.522 billion, an increase of $6.9 \%, 20.5 \%$ and $11.5 \%$ respectively over the previous year. The contribution rate of the three industries to economic growth was respectively $8.87 \%, 63.9 \%$ and $27.23 \%$, which boosted GDP growth by 1.31 percentage points, 9.46 percentage points and 4.03 percentage points respectively. The ratio of the three industrial structures was 16.3: 57.4: 26.3 .

According to China's total social logistics expenditure accounting for about $18 \%$ of GDP, LY City's total social logistics expenditures reach over RMB 3 billion. This huge total market will become a "big cake" competitively carved up by logistics enterprises in LY City. It can be believed that many logistics enterprises will hopefully share this "big cake of total market".

\section{B. Analysis of Logistics Market Development Space in LY City}

The output value of the social logistics industry in developed countries accounted for about $11 \%$ of GDP on average in 1991, and the total social logistics expenditures in America were less than $10 \%$ of GDP. Therefore, based on the GDP level of that year, in case of reaching the same level, LY City will be able to save more than RMB 300 million of logistics costs for the whole society, or in other words, generate more than RMB 300 million of profits. The huge decreased value in social logistics costs brought by the development from traditional logistics to modern logistics is just another "big cake" for logistics enterprises to share in competition. Merely compared with the "big cake of total market", the "big cake of market space" puts more emphasis on the competitive strength of logistics enterprises.

Assuming that China has made great progress in it economic development in the next five years, with rapid and efficient logistics development and logistics costs accounting for $15 \%$ of GDP, the development space of logistics market is about RMB 700 million in LY City.

\section{ANALYSIS OF THE DEMAND ENVIRONMENT OF LOGISTICS MARKET IN LY CITY}

At present, the demand of logistics market in LY City mainly comes from the following aspects:

\section{A. Large Logistics Demand Volume of Agricultural and Sideline Products in LY City}

Currently, LY City has the characteristics of continuously fast growth of agricultural economy, steady development of production, gradual progress in industrialization, further optimization of industrial structure in agriculture, and has initially formed a featured and high-efficiency agriculture dominated by high quality rice industry belt, flowers and trees industry belt, flue-cured tobacco industry belt, and vegetable 
industry belt. The total value of output of agriculture, forestry, animal husbandry and fishery reach RMB 4.51 billion, an increase of $7.3 \%$ over the previous year, of which the agricultural output value is RMB 2.229 billion, an increase of $7.7 \%$, and the forestry output value is RMB 407 million, an increase of $6.4 \%$, and the animal husbandry output value is RMB 1.648 billion, an increase of $7.5 \%$, and the fishery output value is RMB 152 million, an increase of $1.9 \%$, and the output value of agriculture, forestry, animal husbandry and fishery services is RMB 74 million, an increase of $9.1 \%$. Agricultural and sideline products grew by $10.15 \%$ annually in 2014 and 2015 in LY City, with over 1.5 million tons of agricultural and sideline products gestating a huge logistics demand. This paper takes grain of LY City as an example to analyze the logistics demand of agricultural and sideline products.

As the grain is the staple food of the people in LY City, farmer producing and marketing their own products accounts for a large proportion, but the total logistics volume is still relatively large. The proportion of circulation volume of other products, such as cotton, rapeseed, flue-cured tobacco, herbs, and aquatic products, will be much higher than that of grain, at least more than $80 \%$. The proportion of vegetables, meat and aquatic products that are consumed in local areas is relatively large, and the proportion of circulation volume of logistics services required by them is conservatively estimated to be $10 \%$. According to this proportion, we can roughly calculate the logistics demand of grain and agricultural products in LY City at the present stage in "Table I":

TABLE I. ESTIMATION OF AGRICULTURAL AND SIDELINE LOGISTICS DEMAND IN LY CITY IN 2015 (TON)

\begin{tabular}{|l|l|l|l|}
\hline & $\begin{array}{c}\text { Total Output } \\
\text { in 2015 }\end{array}$ & $\begin{array}{c}\text { Proportion of } \\
\text { Logistics Demand } \\
\text { Volume }\end{array}$ & $\begin{array}{c}\text { Estimation of } \\
\text { Logistics Demand } \\
\text { Volume }\end{array}$ \\
\hline Total grain output & 567641 & $3 \%$ & 17029.23 \\
\hline Cotton & 561 & $80 \%$ & 448.8 \\
\hline Rapeseed & 7112 & $80 \%$ & 5689.6 \\
\hline $\begin{array}{l}\text { Flue-cured } \\
\text { tobacco }\end{array}$ & 16506 & $80 \%$ & 13204.8 \\
\hline Ramie & 554 & $80 \%$ & 443.2 \\
\hline Fruit & 98288 & $80 \%$ & 78630.4 \\
\hline Tea & 1536 & $80 \%$ & 1228.8 \\
\hline Vegetable & 648078 & $10 \%$ & 64807.8 \\
\hline $\begin{array}{l}\text { Medicinal } \\
\text { material }\end{array}$ & 13205 & $80 \%$ & 10564 \\
\hline Total meat output & 139139 & $10 \%$ & 13913.9 \\
\hline $\begin{array}{l}\text { Total output of } \\
\text { aquatic products }\end{array}$ & 22000 & $20 \%$ & 4400 \\
\hline Subtotal & 1514620 & ---- & 210360.53 \\
\hline
\end{tabular}

If the average annual growth rate is $5 \%$, the logistics demand volume of grain and agricultural and sideline products in 2020 and 2025 can be calculated as the following "Table II":
TABLE II. FORECAST OF LOGISTICS DEMAND VOLUME OF AgriculturAL AND SiDELINE PRODUCTS IN LY CiTY IN 2020-2025 (TON)

\begin{tabular}{|l|l|l|l|l|l|}
\hline & \multicolumn{1}{|c|}{$\begin{array}{c}\text { Total } \\
\text { output in } \\
\mathbf{2 0 1 5}\end{array}$} & $\begin{array}{c}\text { Proportion } \\
\text { of logistics } \\
\text { demand } \\
\text { volume }\end{array}$ & $\begin{array}{c}\text { Estimation } \\
\text { of logistics } \\
\text { demand } \\
\text { volume }\end{array}$ & $\begin{array}{c}\text { Predicted } \\
\text { volume in } \\
\mathbf{2 0 2 0}\end{array}$ & $\begin{array}{c}\text { Predicated } \\
\text { volume in } \\
\mathbf{2 0 2 5}\end{array}$ \\
\hline $\begin{array}{l}\text { Total } \\
\text { output }\end{array}$ & 567641 & $15 \%$ & 85146.15 & 108670.46 & 138694.11 \\
\hline Cotton & 561 & $80 \%$ & 448.8 & 572.80 & 731.05 \\
\hline Rapeseed & 7112 & $80 \%$ & 5689.6 & 7261.53 & 9267.76 \\
\hline $\begin{array}{l}\text { Flue-cured } \\
\text { tobacco }\end{array}$ & 16506 & $80 \%$ & 13204.8 & 16853.04 & 21509.23 \\
\hline Ramie & 554 & $80 \%$ & 443.2 & 565.65 & 721.93 \\
\hline Fruit & 98288 & $80 \%$ & 78630.4 & 100354.53 & 128080.64 \\
\hline Tea & 1536 & $80 \%$ & 1228.8 & 1568.29 & 2001.59 \\
\hline Vegetable & 648078 & $10 \%$ & 64807.8 & 82713.00 & 105565.08 \\
\hline $\begin{array}{l}\text { Medicinal } \\
\text { material }\end{array}$ & 13205 & $80 \%$ & 10564 & 13482.64 & 17207.64 \\
\hline $\begin{array}{l}\text { Total meat } \\
\text { output }\end{array}$ & 139139 & $10 \%$ & 13913.9 & 17758.05 & 22664.28 \\
\hline $\begin{array}{l}\text { Total output of } \\
\text { aquatic products }\end{array}$ & 22000 & $20 \%$ & 4400 & 5615.64 & 7167.14 \\
\hline Subtotal & 1514620 & & 210360.53 & 355415.64 & 453610.42 \\
\hline
\end{tabular}

\section{B. The Relatively Large Scale of Logistics Demand of Industrial Products}

In 2015, the total industrial output value of LY City reached RMB 20.995 billion, an increase of $31.4 \%$ over the previous year, and the added value reached RMB 7.552 billion, an increase of $22.1 \%$. There were 499 large-scale industrial enterprises and the output value reached RMB 9.098 billion, an increase of $53.27 \%$, accounting for $43.3 \%$ of the total industrial output value. The increased contribution rate for the whole industry reached $63.1 \%$.

The main industrial product categories and recent output of LY City considered in this project are shown in "Table III":

TABLE III. OUTPUT OF INDUSTRIAL PRODUCTS CONSIDERED IN THIS PROJECT IN LY CITY IN 2013-2015 (TON)

\begin{tabular}{|l|l|l|l|l|}
\hline \multicolumn{1}{|c|}{ Categories } & \multicolumn{1}{c|}{ Unit } & \multicolumn{1}{c|}{ In 2013 } & In 2014 & \multicolumn{1}{c|}{ In 2015 } \\
\hline $\begin{array}{l}\text { Nitrogenous } \\
\text { fertilizer }\end{array}$ & Ton & 12783 & 13619 & 13140 \\
\hline Raw coal & Ton & 315600 & 369567 & 351816 \\
\hline Fodder & Ton & 64636 & 176901 & 192614 \\
\hline Cement & Ton & 447200 & 434718 & 400601 \\
\hline Subtotal & Ton & 840219 & 994805 & 958171 \\
\hline
\end{tabular}

The output of industrial products considered in the project of LY City grew by 7\% annually in 2014 and 2015, with an annual average of more than 930 thousand tons of industrial products generating huge logistics demand. Industrial products are different from agricultural and sideline products: if industrial products are produced, there will be a series of logistics demands such as procurement, storage and production logistics of raw material, and storage, transportation and distribution of finished products. Therefore, we can regard its output directly as logistics demand volume. According to its growth rate in recent years (estimated at 5\% per year), we can calculate the logistics demand of industrial products at the present stage in LY City in 2020-2025 in "Table IV". 
TABLE IV. PREdicATEd LOGISTICS DEMAND VOLUME OF INDUSTRIAL PRODUCTS IN THIS PROJECT OF LY CITY IN 2010-2015

\begin{tabular}{|l|l|c|l|}
\hline \multicolumn{1}{|c|}{ Categories } & \multicolumn{1}{c|}{ In 2015 } & In 2020 & \multicolumn{1}{c|}{ In 2025 } \\
\hline $\begin{array}{l}\text { Nitrogenous } \\
\text { fertilizer }\end{array}$ & 13140 & 16770.33973 & 21403.6754 \\
\hline Raw coal & 351816 & 449016.2742 & 573071.192 \\
\hline Fodder & 192614 & 245829.6969 & 313747.9096 \\
\hline Cement & 400601 & 511279.6702 & 652536.8164 \\
\hline Subtotal & 958171 & 1222895.981 & 1560759.593 \\
\hline
\end{tabular}

\section{The Stable and Slightly Declining Logistics Demand of Agricultural Material Consumption}

LY City has an area of 941,400 mu of cultivated land, and there is a large logistics demand of agricultural material consumption products. The amount of consumption of major agricultural products in LY City in 2013-2015 is shown in "Table V":

TABLE V. AMOUNT OF CONSUMPTION OF AGRICULTURAL MATERIAL PRODUCTS IN LY CITY IN 2013-2015

\begin{tabular}{|l|l|l|l|l|}
\hline \multicolumn{1}{|c|}{ Categories } & \multicolumn{1}{c|}{ Unit } & \multicolumn{1}{c|}{ In 2013 } & \multicolumn{1}{c|}{ In 2014 } & \multicolumn{1}{c|}{ In 2015 } \\
\hline Nitrogenous fertilizer & Ton & 53500 & 51100 & 46400 \\
\hline Phosphatic fertilizer & Ton & 29700 & 31700 & 30100 \\
\hline Potash fertilizer & Ton & 13300 & 15200 & 13900 \\
\hline Compound fertilizer & Ton & 31400 & 33000 & 32500 \\
\hline Use of agricultural film & Ton & 1266 & 1122 & 1364 \\
\hline Subtotal & Ton & 129166 & 132122 & 124264 \\
\hline
\end{tabular}

The average annual growth rate of agricultural material products in LY City in 2014 and 2015 was $-1.83 \%$, and the agricultural material products with an annual consumption of more than 120 thousand tons had a huge logistics demand. Agricultural material products are generally not produced by farmers themselves, so there must be a series of logistics demands such as storage, transportation and distribution of agricultural material products. Therefore, we can regard its amount of consumption directly as logistics demand volume. According to its growth rate in recent years (estimated at $-2 \%$ per year), we can calculate the logistics demand of agricultural products in LY City in 2020-2025 in "Table VI".

TABLE VI. PREDICATED LOGISTICS DEMAND VOLUME OF Agricultural MATERIAL PRODUCTS IN LY CITY IN 2020-2025

\begin{tabular}{|l|l|l|l|l|}
\hline \multicolumn{1}{|c|}{ Categories } & \multicolumn{1}{c|}{ Unit } & \multicolumn{1}{c|}{ In 2015 } & \multicolumn{1}{c|}{ In 2020 } & \multicolumn{1}{c|}{ In 2025 } \\
\hline Nitrogenous fertilizer & Ton & 46400 & 41941.92 & 37912.178 \\
\hline Phosphatic fertilizer & Ton & 30100 & 27208.02 & 24593.891 \\
\hline Potash fertilizer & Ton & 13900 & 12564.50 & 11357.312 \\
\hline Compound fertilizer & Ton & 32500 & 29377.43 & 26554.866 \\
\hline Use of agricultural film & Ton & 1364 & 1232.95 & 1114.4873 \\
\hline Subtotal & Ton & 124264 & 112324.81 & 101532.74 \\
\hline
\end{tabular}

\section{The Rapidly Increased Logistics Demand of Residents' Living Consumption in LY City}

The status of per capita living consumption expenditure of residents in LY City in 2013-2015 is shown in "Table VII":
TABLE VII. PER CAPITA LIVING CONSUMPTION EXPENDITURE OF RESIDENTS IN LY CITY IN 2013-2015

\begin{tabular}{|l|l|l|l|l|}
\hline \multicolumn{1}{|c|}{ Categories } & Unit & In 2013 & In 2014 & In 2015 \\
\hline Food & Yuan & 1481 & 1647 & 1776 \\
\hline Clothing & Yuan & 180 & 177 & 279 \\
\hline Residence & Yuan & 540 & 526 & 728 \\
\hline Household equipment and supplies & Yuan & 114 & 160 & 146 \\
\hline Health care & Yuan & 159 & 235 & 257 \\
\hline Traffic communication & Yuan & 287 & 321 & 409 \\
\hline Culture, education and amusement & Yuan & 429 & 434 & 408 \\
\hline Subtotal & Yuan & 3190 & 3500 & 4003 \\
\hline
\end{tabular}

The per capita living consumption expenditure of residents in LY City annually increased by $12 \%$ in 2014 and 2015. With a population of $1,345,410$, LY City has a consumption demand of more than RMB 5.3 billion, and the agricultural material products with an annual consumption of over 120 thousand tons had a huge logistics demand. After statistical analysis, it is found that logistics expenses generally account for about $2.4 \%$ of consumer goods sales amount. According to this proportion, the logistics demand value of residents' living consumption in LY City in 2020-2025 can be roughly estimated in "Table VIII".

TABLE VIII. PREDICATED RESIDENTS' LIVING CONSUMPTION LOGISTICS DEMAND IN LY CITY IN 2010-2015

\begin{tabular}{|c|c|c|c|c|}
\hline Categories & Unit & In 2015 & In 2020 & In 2025 \\
\hline $\begin{array}{l}\text { Residents' consumption } \\
\text { logistics demand }\end{array}$ & Yuan & 129256230 & 208168451 & 335257372 \\
\hline
\end{tabular}

\section{ANALYSIS AND PREDICTION OF DEMAND OF LOGISTICS SERVICE MODES}

In order to accurately grasp the current and future logistics service modes in LY City, we have conducted a three-day survey on the three largest professional markets in LY City. We have distributed 62 questionnaires and collected 56 valid questionnaires, accounting for $90 \%$ of the total content.

Through the analysis of 56 valid questionnaires obtained from the above three markets, we have a more comprehensive understanding of several major commercial and wholesale markets and their logistics demands in LY City. The main non-agricultural consumer goods in LY City are basically supplied by the area outside the city. The supply from Hunan Province accounts for $46.7 \%$, of which the supply from Changsha, Zhuzhou and Xiangtan accounts for $26.7 \%$, and the supply from other provinces accounts for 50\%. In the transportation of these foreign consumer goods, $50 \%$ of them are transported by manufacturers or superior agents, and $29 \%$ of them are transported by the third-party, and $9 \%$ of the merchants adopt composite transportation. At present, the method of bulk procurement is still a procurement method used mostly by merchants, accounting for $68.9 \%$, and a large number of warehouses outside the shop front are needed. From the survey results in the fourth and seventh questions, we can also see that $54.8 \%$ of the merchants need warehouse to store goods, and the average monthly sales of most merchants remain in small to medium batches. At the same time, we learn through the visit that the current storage conditions and management level of these warehouses are poor and almost belong to zero management, and most of 
them are concentrated around the market. These facts show that logistics level in LY City is in a primary stage, but also indicate that enterprises taking third-party logistics as a main form in LY City have a large development space, which can provide large-scale parking lot for the logistics center of storage type.

Second, the sales target of these wholesale markets is mainly for the LY city area, and the radiation capacity is small. The goods delivery takes their own vehicles as the main means or is responsible by the seller, but the ability of third-party freight also cannot be ignored. Most of the powerful enterprises have their professional distribution teams, while distribution vehicles for individuals and small businesses are simple. They generally use tricycles, which are time-consuming and laborious. The single delivery capacity is small, and the scope is basically limited to urban distribution.

Third, most merchants do not have high requirements for logistics services, and $90 \%$ of them are basically satisfied with the current logistics services. Most people regard logistics as transportation, and it can be seen from the results of the survey on the causes of dissatisfaction, they do not understand the value-added services of logistics. In the choice between service and cost, which are two factors with antinomy, most of them tend to choose the cost, which may be related to the small scale of the merchant. Therefore, in the construction of this project, the public opinion publicity at the early stage should be strengthened to enhance people's understanding of logistics, and the invested cost should be controlled well, and the facilities can be properly and rationally.

\section{CONCLUSION}

Based on the analysis and forecast of total logistics market and development space, demand environment of logistics market, and need of logistics service modes in LY City, it can be preliminarily concluded that the comprehensive grain logistics park in LY City of Hunan has a good construction foundation, and the construction of the project will vigorously promote the development of regional grain logistics industry.

\section{REFERENCES}

[1] Hu Feifan, Shi Guoqing, Wu Zhihua. Analysis on Characteristics and Trend of Chinese Grain Logistics Center. On Economic Problems [J]. 2007, 02.

[2] Meng Ling. Feasibility Study on Project of Grain Emergency Logistics Base Construction in Xi'an [D]. Chang'an University. 2016.

[3] Zhu Xuanyu. Design and Research of Qiqihar Grain Logistics Center [D]. Jilin University. 2016. 